\title{
Internal Marketing: Study of Lecturer Organizational Commitments on Private University in Indonesia
}

\author{
Uswatun Chasanah $^{1^{*}} \quad$ Anas Hidayat $^{2} \quad$ Zainal Mustafa $^{2}$ \\ 1.Ph.D. Student in Economics Postgraduate Study, Faculty of Economics, Islamic University of Indonesia, \\ Condongcatur, Yogyakarta \\ 2.Postgraduates Study Faculty of Economics, Islamic University of Indonesia, Condongcatur, Yogyakarta
}

\begin{abstract}
The purpose of this research is to examine the organizational commitment model based on a three component of organizational commitment (Meyer, Stanley, Herscovitch, \& Topolnytsky, 2002). This research used multidimensional variables that affect organizational commitment in an integrated manner namely religiosity, internal marketing, organizational justice and job satisfaction. The method of data collection was done by using a survey through questionnaire. The number of samples of 200 people used non-probability sampling with a purposive sampling method. Description of respondents' assessments of constructs had a higher mean value than the standard deviation of 4 and 5 , which means that the research construct was good and very good. The results of the SEM assumption tests were all normally distributed data with a critical ratio of \pm 2.58 . Measurement model test results using confirmatory factor analysis (CFA) were all valid indicators which confirmed latent variables. Validity used convergent validity with a loading factor $\geq 0.50$. The reliability test resulted construct validity $\geq 0.70$, while the results of the variance extracted above $\geq 0.50$. The structural model modification test results can be seen from the goodness of fit that showed the value of good fit. Not all hypotheses were proven, internal marketing affected organizational justice, organizational justice influenced job satisfaction, job satisfaction was proven to affect organizational commitment and internal marketing was proven to influence organizational commitment mediated by organizational justice and job satisfaction. Overall, the results of this research indicated that organizational commitment was influenced by various factors, namely internal marketing, organizational justice and job satisfaction, while religiosity either directly or indirectly did not affect organizational commitment.
\end{abstract}

Keywords : religiosity, internal marketing, organizational justice, job satisfaction, organizational commitment. DOI: $10.7176 / \mathrm{EJBM} / 12-2-06$

Publication date: January $31^{\text {st }} 2020$

\section{Introduction}

Organizational commitment has been subject to increasing discussion lately, organizational commitment has been examined in various disciplines ranging from organizational behavior, sociology, marketing and accounting. The term commitment is often used in daily communication, but commitment is not as simple as practical meaning. This concept has evolved from time to time since 1960 and shows a shift in the flow of thought that changes the way of view of commitment, definition, and measurement. In the organizational context, the premise underlying this concept does not change, organizational commitment is based on the premise that individuals form an attachment to the organization (Ketchand \& Strawser, 1998). Employee commitment to the organization is described as a form of engagement, identification and individual involvement with the organization (Brooks, 2002). The higher the employee's commitment to the organization the lower the employee's desire to leave the organization (Loi, Hang-Yue, \& Foley, 2006). Organizational practitioners and academics realize that organizational commitment is an important factor that determines organizational effectiveness, refer to organizational commitment as a psychological construct that connects organizational members with their organizations and has implications for individual decisions to remain or leave the organization (Meyer \& Allen, 1991)

Several studies have identified factors that determine organizational commitment, including job satisfaction. The relationship between organizational commitment and job satisfaction, the higher the job satisfaction the higher the employee's commitment to the organization (Laschinger \& Finnegan, 2005). Job satisfaction is an antecedent that influences organizational commitment.(Testa, 2001). Extrinsic job satisfaction and intrinsic job satisfaction have a significant effect on organizational commitment (Veličković et al., 2014). There are two main components in job satisfaction, namely affective (emotional) and cognitive. Therefore, individual assessment related to job satisfaction is the extent to which work can cause positive emotional satisfaction or vice versa (Coomber \& Louise Barriball, 2007). Job satisfaction is a pleasant or positive emotional state that results from the assessment of one's work or work experience (Locke, 1976). This definition looks at job satisfaction from an affective perspective linked to one's emotions.

One of the factors that contribute to build job satisfaction and organizational commitment is organizational justice Organizational justice is important. Perceptions of organizational justice influence the opinions, feelings, 
and behavior of employees towards the organization (Hawkins \& Parks, 1998). The research showed that the higher perception of organizational justice about promotion, performance appraisal and remuneration influences organizational commitment (Yiğitol \& Balaban, 2018). Perception of organizational injustice brings undesired results by the organization and results in job dissatisfaction, decreased performance, lack of trust in the organization, career obstruction, and negative emotions towards the organization. There are three dimensions of organizational justice, namely distributive justice, procedural justice, and interactional justice. Distributive justice refers to justice perceived by individuals from the organization. Received results are distributed based on equality, needs or contributions between individuals (Alsalem \& Alhaini, 2007). Procedural justice refers to the individual's perception of the reasonableness of the rules and procedures governing the process (Nabatchi, Blomgren Bingham, $\&$ Good, 2007). Interactional justice is defined as the quality of managing interpersonal relationships according to procedures in force in organizations (Bies \& Moag, 1986).

Studies showing antecedents in organizational commitment such as organizational justice, job satisfaction and attitudes have been studied empirically, but few consider the antecedents from the aspect of religiosity, especially in the field of education. Religiosity is an interpersonal relationship between human and God, as well as patterns that govern human life to be more organized (Siswato, 2007). Religiosity is a system that has many dimensions and is manifested in various spheres of life, both visible and invisible to humans (Ancok \& Suroso, 1994). The initial study of the role of religion was carried out on his observation that there were controversial conditions in a person. one side is religious, but on the other hand it is contrary to his religion (Allport \& Ross, 1967). Their study put forward two approaches to religious orientation namely extrinsic religious orientation and intrinsic religious orientation. The fundamental differences of these two approaches lie in individuals seeing their religion. Despite the conceptual difficulties, these two approaches have generally accepted (Allport \& Ross, 1967). Studies that examine the effect of religion on commitment shows that religion is important in shaping people's attitudes and behavior. Religion is an important cultural factor which is one of the most universal social institutions and has a significant influence on people's attitudes, values and behavior, both on the individual and social level (Mokhlis, 2009). Religion is an important value in cognitive structure that can influence individual behavior (Delener, 1994).

In line with previous studies that examined various factors that influence organizational satisfaction and commitment, several other studies identified the importance of internal marketing in building organizational satisfaction and commitment. The study revealed that internal marketing has the aim of establishing and maintaining organizational commitment, commitment to the organization fostering service-oriented behavior in order to increase customer satisfaction and loyalty (Barnes, Fox, \& Morris, 2004). Internal marketing was firstly defined as: employees are internal customers and jobs are products (Berry, Hensel, \& Burke, 1976). Employees are internal customers who will serve external customers. Thus, employees who have job satisfaction are important in order to satisfy external customers. There are quite a lot of internal marketing researches done, but relatively few have systematically examined the process of how it is implemented in organizational practices, especially in tertiary institutions which is mainly related to organizational commitment. The purpose of this study is to examine the model of organizational justice relationships, religiosity, internal marketing and job satisfaction with the organizational commitment of lecturers in private universities under the management of the Higher Education Service Institutions in Indonesia.

\section{Literature Review and Hypothesis Development 2.1. Religiosity}

The terms spirituality and religiosity are often used interchangeably and have the same benefits (Brega \& Coleman, 1999). Distinguishes between spirituality and religiosity, religiosity classically includes belief systems and personal, family, and work-related commitments (Brandt, 1996). Spirituality is understood as a rather broader concept of individual development as a whole human being, in other words religiosity has an element of acting on one's belief system or religious tradition while spirituality is a dimension of personality including beliefs and values which include perceptions of one's life. Most empirical research on religiosity found that religiosity offers beneficial effects for people from the point of view of psychology, health, business and management. Religiosity is a vital element of human experience (Stuckey, 2001) and provides a strong sense of personal identity (Pecchenino, 2009).

Religiosity and spirituality have a positive relationship with life satisfaction, self-esteem, physical, mental health, and negatively associated with depression and suicide (Brega \& Coleman, 1999). Research on the effect of religiosity on job satisfaction shows that religiosity leads to life satisfaction, work becomes a mode of satisfaction when they relate it to their religion, that work is worship (Farwa, Moazzam, \& Nighat, 2015). It analyzed that religious values provide a mechanism for overcoming the adverse social impacts caused by dissatisfaction at work. It can be observed that religious people are more satisfied in all situations whether they are stressed or not. They are more hopeful in their lives that things will change, if they are stressed, they pray to God and try to find solutions to their problems. Employee religiosity acts as a buffer that reduces work stress by providing coping 
mechanisms that ultimately results in job satisfaction. Empirical studies of the phenomenon of religiosity in American industry concluded that most organizations in America suffer from poverty of religiosity (Mitroff \& Denton, 1999).

One of the biggest challenges facing leaders today is the need to develop new business models that feature religiosity, leadership, employee welfare, sustainability, and social responsibility without compromising revenue growth, and other financial indicators, referred to as' tripple bottom line; people, planet, profit (Fry \& Slocum, 2008). The study found that religiosity can be a culture to improve organizational performance, as well as it was found that organizational culture based on religiosity is the most productive and can maximize productivity and satisfaction (Reder, 1982). Religiosity is a necessary driving force toward more meaningful work (Gotsis \& Kortezi, 2008). Religiosity contributes to making it better in building organizational commitment, job satisfaction and productivity in organizations (Ghozali, 2002). Based on the background of the theory, the hypothesis is formulated as follows:

H1: Religiosity influences organizational justice.

H2: Religiosity affects job satisfaction.

H3: Religiosity influences organizational commitment.

\subsection{Internal marketing}

The concept of internal marketing has attracted the interest of researchers and marketing practitioners especially in service organizations over the past two decades. The concept of internal marketing emerged in the marketing literature in 1970 and was developed with the statement that external customers are satisfied. However, the organization must satisfy employees first (Berry, 1981). An internal marketing study was done to improve service quality (Sasser \& Arbeit, 1976). The study of internal marketing for external implementation of marketing programs was carried out (Piercy \& Morgan, 1991). The internal marketing to motivate employees (Gronroos, 1985).

The concept of internal marketing has evolved from the initial concept of conceptualizing employee satisfaction / motivation by treating employees as customers and working as products. The implementation of internal marketing in a competitive situation can be used as one of the differentiations to achieve competitive advantage. Various literatures on the concept of internal marketing are widely discussed and conclusions can be drawn all focus on the coordination and motivation of internal employees who serve external customers in order to achieve a higher customer orientation (Yildiz \& Kara, 2017). The study of internal marketing in organizations is related to job satisfaction and organizational commitment (Sihombing \& Gustam, 2007). There is empirical evidence of the influence of internal marketing and organizational commitment with satisfaction as the mediator (Bansal, Mendelson, \& Sharma, 2001). Internal marketing is the best approach to achieving organizational commitment (Caruana \& Calleya, 1998). Internal marketing can increase job satisfaction and organizational commitment (Collins \& Payne, 1991; Rafiq \& Ahmed, 2000; Tansuhaj, Randall, \& McCullough, 1988). The research showed that internal marketing has a positive effect on organizational justice (Aykan \& Sönmez, 2014). Based on this background, the hypothesis is formulated as follows:

H4: Internal marketing influences organizational justice

H5: Internal marketing has an effect on job satisfaction.

H6: Internal marketing influences organizational commitment.

\subsection{Organizational Justice}

Over the past 30 years, organizational justice has been extensively investigated in social psychology, especially in the organizational context by psychologists and management researchers. The concept of organizational justice is central to understand various human behaviors in organizational management (Hartman, Yrle, \& Galle, 1999). The term organizational justice refers to employees' perceptions of fairness at work (Greenberg, 1987). This has been proven to be linked to several research results such as job satisfaction, work motivation, intention turnover (Colquitt, 2001). Organizational justice has proven to be a predictor of many behavioral research results. Therefore, managers try to maximize the work satisfaction of their employees.

The research examined the impact of the organizational justice dimension on the job satisfaction of employees working in Iranian banks (Sepah banks) in the city of Ilam (Abasi, Mohammadipour, \& Aidi, 2014). The sample consisted of 110 participants with 105 questionnaires. The results showed that three dimensions of organizational justice including distributive, procedural and interactional justice significantly affected overall employee job satisfaction. Of the three dimensions of distributive justice is the strongest predictor. It is also found that female employees are more satisfied with work than male employees. The research examined the effects of procedural and interactional justice on various work-related social exchange relationships. It was found that procedural justice was positively correlated with job satisfaction. The samples for this research were employees of various companies in the United States (Masterson, Lewis, Goldman, \& Taylor, 2000).

The perception of organizational justice as a predictor of job satisfaction and organizational commitment 
(Bakhshi, Kumar, \& Rani, 2009), distributive justice and procedural justice were found to be significantly related to organizational commitment. The research found that employees who felt treated fairly by the company tended to develop and maintain a communal relationship with the company. When employees feel that they are treated fairly by their company, they tend to have more commitment, trust, satisfaction, and mutual control than when they feel treated unfairly (Kim, Kim, \& Kim, 2009). The study found that the higher level of employee perceptions of fairness that is the way used to determine results (procedural fairness) and fairness of the results received by employees (distributive justice) tended to increase employee job satisfaction, organizational commitment while reducing intentions turnover, organizational justice will shape job satisfaction and organizational commitment (Fatt, Khin, \& Heng, 2010). Based on these thoughts and findings, the hypothesis is structured as follows:

H7: Organizational justice influences organizational commitment.

H8: Organizational justice influences job satisfaction.

\subsection{Job Satisfaction}

Previous research shows that organizational commitment is influenced by job satisfaction. The research found that the higher job satisfaction, the higher employee commitment to the organization (Laschinger \& Finnegan, 2005). The relationship between job satisfaction and service efforts towards organizational commitment shows job satisfaction is an antecedent of organizational commitment. Increasing job satisfaction becomes a driver in increasing organizational commitment (Testa, 2001). The study at health institutions found extrinsic job satisfaction and intrinsic job satisfaction significantly influence organizational commitment (Veličković et al., 2014). In the service context especially in the fire department stated that job satisfaction significantly influences organizational commitment, intrinsic satisfaction and extrinsic satisfaction has a significant effect on organizational commitment.

Research on job satisfaction, organizational commitment of teachers and principals shows that teachers are the main factor while the headmaster's leadership is the second factor influencing school success (Leithwood, Seashore, Anderson, \& Wahlstrom, 2004). Teachers and principals who are satisfied at work will influence student satisfaction and organizational commitment (Fraser \& Brock, 2013). The organizational satisfaction and commitment of teachers and principals influences school performance (Leithwood et al., 2004; Yousef, 2017). Research on job satisfaction and organizational commitment in higher education was conducted, higher education has a unique social environment, managerial factors and physical environment factors that influence job satisfaction and organizational commitment, likewise the quality of learning, academic atmosphere, structural environment including the relationship between management and lecturers, employees and students significantly affects organizational satisfaction and commitment (Cohen, Holley, Wengel, \& Katzman, 2012). Based on these thoughts the hypothesis is structured as follows:

H9: Job satisfaction influences organizational commitment.

\subsection{Organizational commitment}

The definition of organizational commitment can be seen from various perspectives, as an attitude, defined organizational commitment as: (1) a strong desire to be a member of a group, (2) a high level of business for the organization, (3) certain beliefs and acceptance of the values and goals of the organization (Luthans, 1992). Organizational commitment is defined as an enduring desire to maintain valuable relationships (Moorman, 1991). Organizational commitment is defined as the level of psychological involvement of members in a particular organization (Gruen, Summers, \& Acito, 2000). This psychological involvement is reflected in the level of activity of a person in an organization and for the benefits of the organization.

There are 3 components in organizational commitment, namely affective commitment, continuance commitment and normative commitment (Allen \& Meyer, 1990). Affective commitment is the level of psychological attachment to an organization based on how good it feels about the organization (Gruen et all., 2000). This type of commitment arises and develops by encouraging comfort, security, and other benefits felt in an organization that is not obtained from another place or organization. The more comfortable and greater the benefits felt by members, the higher one's commitment to the organization he chooses. Continuance commitment is a psychological attachment to members of the organization because of the costs that must be borne if leaving the organization (Gruen et al., 2000). Organizational members will calculate the benefits and sacrifices of involvement in becoming a member of an organization. Members tend to have high commitment in membership if the sacrifice due to leave the organization is higher. Normative commitment is the psychological attachment of members to the organization because of the moral obligation to maintain relationships with the organization. This is related to something that encourages members to stay and contribute to the organization, both material and non material, namely the moral obligation of someone who will feel guilty and feel uncomfortable if they do not do something for the organization (Gruen et al., 2000).

The willingness of employees to contribute to the achievement of organizational goals is significantly influenced by their commitment to the organization (Hackett, Bycio, \& Hausdorf, 1994). The cause of affective 
commitment is more related to work experience that can satisfy the psychological needs of individuals so they feel comfortable doing work. The causes for the development of ongoing commitment and normative commitment are more related to matters outside of the direct work experience. Commitments from coworkers, reliable workplace organizations and forms of participatory management are things that are identified as giving rise to normative commitments. While ongoing commitments develop as a result of various events which increases the costs that must be borne if leaving the organization.

Seniority, career satisfaction, pensions, and support from colleagues are some of the considerations that have a strong connection with ongoing commitment. Based on an organizational perspective and investigation, it was conducted to determine the strength of the relationship between patients and health care providers (Peltier, Pointer, \& Schibrowsky, 2006). The results showed job satisfaction and loyalty could be improved through internal marketing efforts through strong ties with doctors, nurses and services other organizations which ultimately has an impact on job satisfaction and organizational loyalty. Studies examining nurse satisfaction shows a relationship between job satisfaction, trust and organizational commitment (Laschinger \& Finnegan, 2005). Organizational commitment negatively related to intention to leave the company (Loi et al., 2006). Furthermore, research related to organizational commitment is examined from an aspect that is rarely observed, namely religiosity. Religiosity is a necessary driving force towards more meaningful work (Gotsis \& Kortezi, 2008). Moreover, religiosity contributes to make it better in building organizational commitment, job satisfaction and productivity in organizations (Ghozali, 2002). Interest in religiosity at work has emerged over the last few decades (Bell \& Taylor, 2004; Carrol, 2013; Louis Fry \& Kriger, 2009; Fry \& Nisiewicz, 2013; Hicks, 2003), who examined the relationship of religiosity into organizational functions and practices, research that examined the relationship of religiosity in the management process was carried out (Dean, Forniciari, \& Safranski, 2008) and into leadership practices (Chen \& Yang, 2012; Chen, Yang, \& Li, 2012). Based on these thoughts, the hypothesis is structured as follows:

H10: Religiosity influences organizational commitment mediated by organizational justice and job satisfaction.

H11: Internal marketing influences organizational commitment mediated by organizational justice and job satisfaction.

The theoretical framework of this study is as follow:

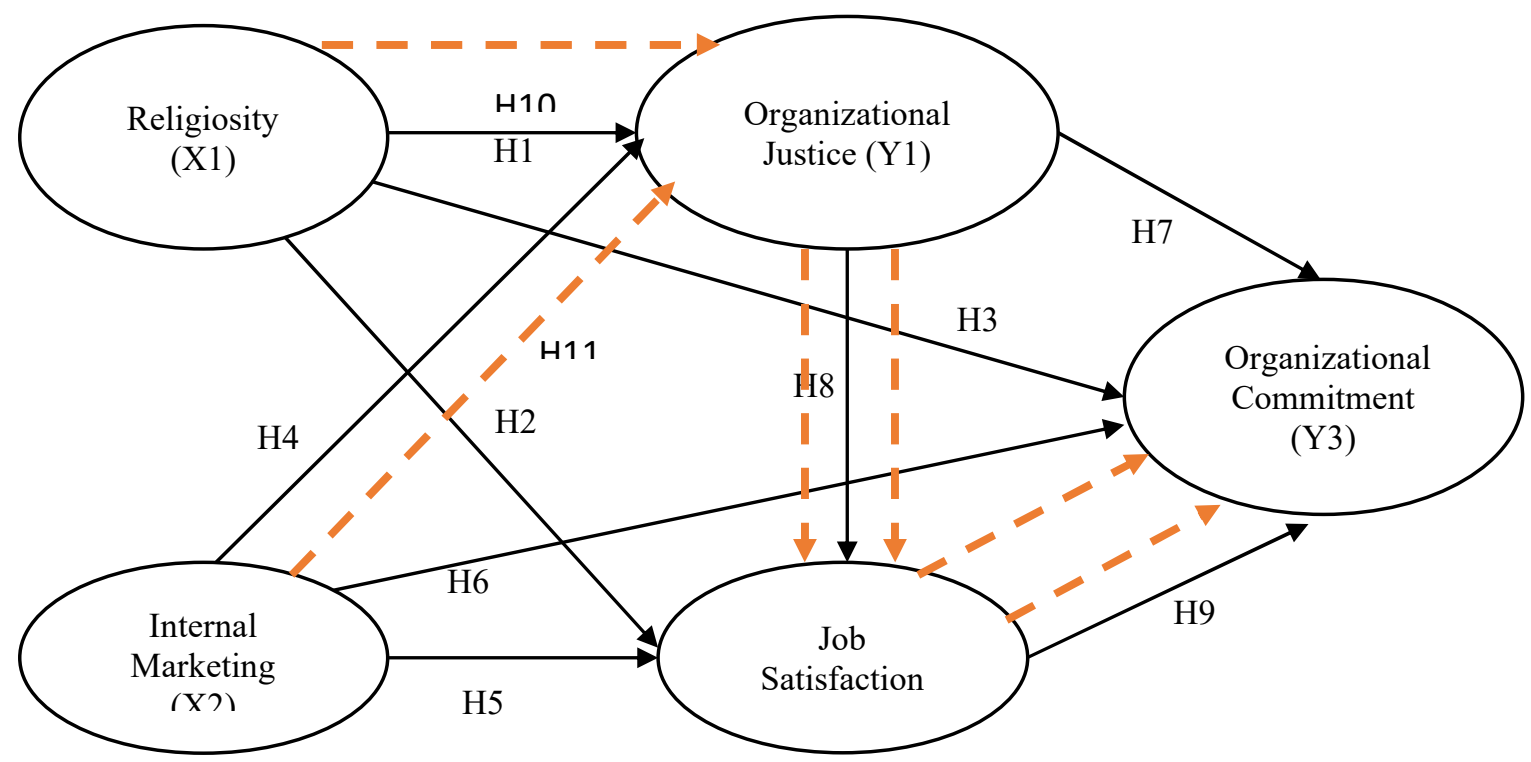

Figure 1. Theoretical Framework

\section{Population and Sample}

The population frame in this research were all Lecturers in the Faculty of Economics and Business in Private University (PTS) in Indonesia, considering that only study programs at the Faculty of Economics and Business because same study program tends to have similar characteristics compared to among study programs. The sampling method used purposive sampling to choose respondents based on certain criteria that have the 
characteristics of the population. Certain criteria determined are PTS lecturers with institutional accreditation and at least B study programs with the consideration that PTS with accreditation of institution B and accreditation of Economics and Business Study Program B is more numerous and the process of forming organizational commitment has been better. The lecturers who became the research sample were lecturers who had National Lecturer Identification Number (NIDN), meaning lecturers who were truly registered as national lecturers. There 200 samples used in this research which provides a general reference in determining the sample size at least 5 times the number of indicators used (Sekaran, 2003), for the Maximum Likelihood Estimation Technique requires samples ranging from 100-200 samples. Guidelines for measuring samples according to Hair et al., (2006) can be determined based on the estimated number of indicators, the guideline is 5-10 times the number of estimated parameters. The number of research samples using Structural Equation Model (SEM) analysis requires at least five times the number of indicators used in the study ranging from 150 to 400 data (Hair, Black, Babin, Anderson, \& Tatham, 2006; Sekaran, 2003). Thus the sample size of 200 lecturers in this reserach had fulfilled the range determined (Hair et al., 2006; Sekaran, 2003).

\section{Result and Discussion}

\subsection{Questionnaire Response}

The data in this research were collected by sending questionnaires using Google form both through the Whats App group and a private network to the lecturers of the Faculty of Economics of Higher Education (PTS) accredited under the coordination of Higher Education Service Institutions (L2Dikti) throughout Indonesia. To ensure data collection procedures can be accounted for and the respondent's answer to the questionnaire statement was accordance with research criteria, the respondent's e-mail address was included in the questionnaire to make it easier for researchers to confirm. Descriptions of respondents' assessments of the constructs tested were good and very good with the mean value of 4 and 5 . These values were above the standard deviation.

\subsection{Measurement Model}

Measurement model aims to get a construct or latent variable that fit so that it can be used for the next stage of analysis. Before conducting a structural analysis, the validity and reliability of the construct indicators were tested. The validity of the research data was determined by an accurate measurement process. A measuring instrument was said to be valid if the instrument measures what should be measured or in other words the instrument can measure the construct as expected by the researcher (Indriantoro \& Supomo, 1999). There are two elements that cannot be separated from the principle of validity, namely the element of accuracy and precision. Accuracy is how far the measuring tool can accurately reveal the symptoms to be measured, while precision is how far the measuring tool can show the actual status and symptoms or the part being measured. In this research, to measure the level of validity, it was carried out using Confirmatory Factor Analysis (CFA). Factor analysis is used to test whether the statement items or indicators used can confirm a factor or construct or variable under study (Ghozali, 2013). According to Latan in Haryono (2016) Confirmatory Factor Analysis (CFA) is used to test the dimensionality of a construct or latent variable. CFA is a technique used in SEM to determine whether indicator variables really measure the latent variables under study. Based on the regression results from the indicator variables to the latent variables all indicators are declared valid with a significance value of 0.001 less than 0.05 . Validity can also be seen from the value of convergent validity or the loading factor value of each indicator. This research used the convergent validity criterion of 0.50 , based on the results of the standardized estimates. All indicators in the research had a loading factor $>0.50$ meaning that the valid indicator measures the construct of the study. The convergent validity value $>0.50$ is still acceptable (Ghozali, 2013).

Reliability is a measure of internal consistency of indicators of a construct that shows the degree of ability of each indicator to indicate a construct or simply can be said as the level of consistency and stability of a measuring instrument (Ferdinand, 2002). High reliability results provided confidence that the indicator was consistent with the measurement. The level of reliability was generally accepted $\geq 0.70$ while the reliability $\leq 0.70$ can be accepted with the terms of the validity of the indicators in a valid model (Ghozali, 2013). There were 2 reliability tests namely Construct Reliability and Variance Extracted. Variance Extracted showed the amount of variance of the indicator extracted by the formed variable developed. The high variance extracted value indicated that the indicators were well represented, the recommended value for the variance extracted value was $\geq 0.50$, thus it can be concluded that the variance of the extracted indicators was well represented. 




Source: Processed Primary Data (2019)

Figure 2. Structural Early Stage Model

After analyzing the measurement model, the next step in SEM modeling was the analysis of structural equations. To get a complete structural equation that matches (fit), it must go through the process of testing the goodness of fit. Following are the steps taken to develop structural equations, namely assessment of goodness of fit, modification of models and testing of hypotheses.



Table 1. Early Stage Goodness of Fit Test Results

\begin{tabular}{|l|c|c|c|}
\hline \multicolumn{1}{|c|}{ Goodness of Fit } & Cut off value & Results & Decision \\
\hline Chi Square Probability & $\geq 0.05$ & 0,000 & Bad Fit \\
\hline CMIN / DF & $\leq 2.00$ & 1,592 & Good fit \\
\hline GFI & $\geq 0.90$ & .806 & Bad Fit \\
\hline CFI & $\geq 0.90$ & 0.912 & Good fit \\
\hline TLI & $\geq 0.90$ & 0.905 & Good fit \\
\hline RMSEA & $\leq 0.08$ & 0.055 & Good fit \\
\hline
\end{tabular}

Source: Primary Processed Data (2019)

The probability value of the structural model at the initial stage was still less than 0.05 , the model cannot be said to be good and cannot be used to test the hypothesis. Therefore, the next process was the modification model. Modification of the model was done by connecting with the covariance lines between variables in the model as recommended by AMOS in the Modification Indices output. This refers to the theory which stated that the correlation between error variables (unique factor covariance) will always appear when several statements are made at one time ie errors in one item statement will have a positive effect on the errors of other items (Rozeboom, 1966). The addition of connections between variables by taking into account the value of modification indices is carried out until the model is declared fit. Based on the results of the covariance relationship test, the value of Modification Indices $(\mathrm{MI}) \geq 3.84$, which indicated a significant decrease in chi-square. Testing the goodness of fit of the research model with covariance variables produced Chi Square $(\chi 2)$ of 292,205 with a probability of 0.104 $\geq 0.05$. 


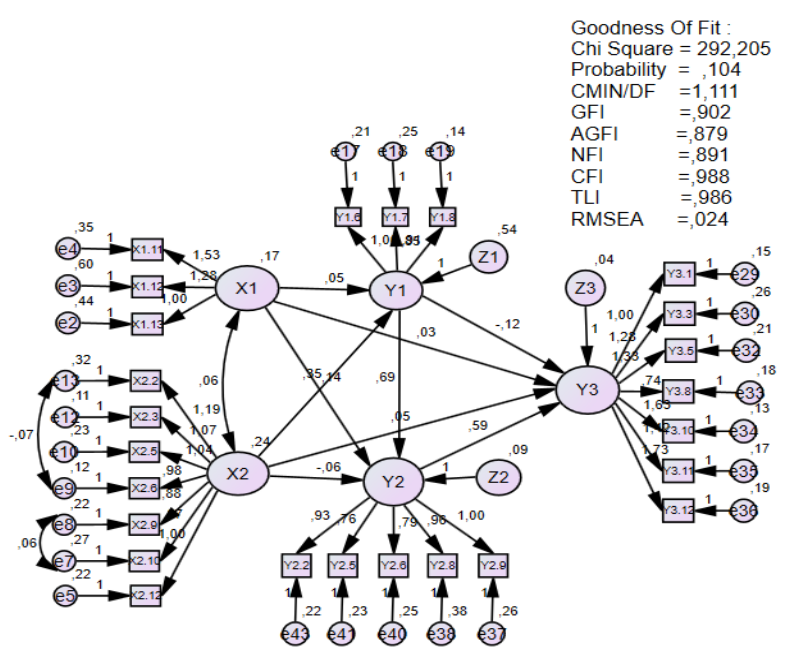

Source: Processed Primary Data (2019)

Figure 3. Full Structural Modified Model

The regression equation based on the model is as follows :

$\mathrm{Y} 1=0.028 \mathrm{X} 1+0.226 \mathrm{X} 2+\varepsilon 1$

$\mathrm{Y} 2=0.096 \mathrm{X} 1-0.051 \mathrm{X} 2+0.867 \mathrm{Y} 1+\varepsilon 2$

$\mathrm{Y} 3=0.035 \mathrm{X} 1+0.073 \mathrm{X} 2-0.268 \mathrm{Y} 1+1.012 \mathrm{Y} 2+\varepsilon 3$

Table 2. Test Results for Goodness of Fit Model Modification

\begin{tabular}{|l|c|c|c|}
\hline \multicolumn{1}{|c|}{ Goodness of Fit } & Cut off value & Results & Decision \\
\hline Chi Square Probability & $\geq 0.05$ & .104 & Good fit \\
\hline CMIN / DF & $\leq 2.00$ & 1.111 & Good fit \\
\hline GFI & $\geq 0.90$ & .902 & Good fit \\
\hline CFI & $\geq 0.90$ & 0.988 & Good fit \\
\hline TLI & $\geq 0.90$ & .986 & Good fit \\
\hline RMSEA & $\leq 0.08$ & 0.024 & Good fit \\
\hline
\end{tabular}

Source: Processed Primary Data (2019)

\subsection{Hypothesis Testing}

Hypothesis testing was done to answer the problems raised in this research. Hypothesis testing is done by testing the null hypothesis $\left(\mathrm{H}_{0}\right)$, where $\mathrm{H}_{0}$ will be accepted if the $\mathrm{p}$ value $>0.05$ or vice versa, the null hypothesis $\left(\mathrm{H}_{0}\right)$ will be rejected. The alternative hypothesis $\left(\mathrm{H}_{\mathrm{a}}\right)$ is accepted if the value of $\mathrm{p}<0.05$. For more details, the results of regression weights and the achievements of $\mathrm{p}$ values can be seen in the following Table 3 :

\section{Table 3. Hypothesis Testing}

\begin{tabular}{|c|c|c|c|c|c|c|c|}
\hline \multirow[b]{2}{*}{$\begin{array}{l}\text { Significant } \\
\text { Influence }\end{array}$} & \multicolumn{3}{|c|}{ Direct Effect Path coefficient } & \multicolumn{3}{|c|}{ Indirect Effect Path Coefficient } & \multirow[b]{2}{*}{ Conclusion } \\
\hline & Standardized & P-value & Significant & Mediating Variable & $\begin{array}{c}\text { Standard } \\
\text { ized }\end{array}$ & Significant & \\
\hline $\mathrm{X} 1 \rightarrow \mathrm{Y} 1$ & 0.028 & .772 & $\begin{array}{c}\text { Not } \\
\text { Significant }\end{array}$ & & & & Not proven \\
\hline $\mathrm{X} 1 \rightarrow \mathrm{Y} 2$ & 0.096 & 0.170 & $\begin{array}{c}\text { Not } \\
\text { Significant }\end{array}$ & & & & Not proven \\
\hline $\mathrm{X} 1 \rightarrow \mathrm{Y} 3$ & 0.035 & 0.653 & $\begin{array}{c}\text { Not } \\
\text { Significant }\end{array}$ & & & & Not proven \\
\hline $\mathrm{X} 2 \rightarrow \mathrm{Y} 1$ & .226 & 0.008 & Significant & & & & Proven \\
\hline $\mathrm{X} 2 \rightarrow \mathrm{Y} 2$ & $-0,051$ & .393 & $\begin{array}{c}\text { Not } \\
\text { Significant }\end{array}$ & & & & Not proven \\
\hline $\mathrm{X} 2 \rightarrow \mathrm{Y} 3$ & 0.073 & .279 & $\begin{array}{c}\text { Not } \\
\text { Significant }\end{array}$ & & & & Not proven \\
\hline $\mathrm{Y} 1 \rightarrow \mathrm{Y} 3$ & $-0,268$ & 0.142 & $\begin{array}{c}\text { Not } \\
\text { Significant }\end{array}$ & & & & Not proven \\
\hline $\mathrm{Y} 1 \rightarrow \mathrm{Y} 2$ & 0.867 & .001 & Significant & & & & Proven \\
\hline $\mathrm{Y} 2 \rightarrow \mathrm{Y} 3$ & 1,012 & .001 & Significant & & & & Proven \\
\hline & & & & $\begin{array}{c}\mathrm{X} 1 \rightarrow \mathrm{Y} 1 \rightarrow \\
\mathrm{Y} 2 \rightarrow \mathrm{Y} 3\end{array}$ & .115 & Not Significant & Not Proven \\
\hline & & & & $\begin{array}{c}\mathrm{X} 2 \rightarrow \mathrm{Y} 1 \rightarrow \\
\mathrm{Y} 2 \rightarrow \mathrm{Y} 3\end{array}$ & 0.085 & Significant & Proven \\
\hline
\end{tabular}

Source: Processed Data (2019) 


\subsubsection{Hypotheses Related to Organizational Justice}

First, internal marketing influences organizational justice. The results of this research proved that in accordance with previous assumptions, internal marketing affects organizational justice. This result is in line with previous research (Aykan \& Sönmez, 2014) on 157 service company employees at the Kayseri shopping center, Turkey. The results of his research showed that first, the internal marketing is carried out by service companies on employees that has an influence on organizational justice. Second, internal marketing has a positive and significant effect on employee performance. The research recommends that businesses implement internal marketing practices that allow employees to feel the values of organizational justice in business. Perception of organizational justice is important for both individuals and society. Perceptions of organizational justice influence opinions, feelings, and behavior toward organizations (Hawkins \& Parks, 1998) and this applies universally including to lecturers of Private Universities in Indonesia. Organizations must pay attention to the practice of organizational justice including all functions regarding employees which must be carried out on an equal basis. Higher perceptions of fairness regarding promotion, performance appraisal, wage practices give rise to higher organizational commitment. Perceptions of injustice felt by employees bring undesired results of the organization and even lead to job dissatisfaction, decreased performance, lack of trust in the organization (Yiğitol \& Balaban, 2018).

Second, religiosity influences organizational justice. The results of this research were not able to prove that religiosity affected organizational justice. This result was in line with previous research that religiosity does not affect organizational justice. The findings of this research were in line with research ever conducted. Based on the research, there is a controversial condition in a person that is on one side religious but on the other hand he does things that are contrary to religion such as unfair behavior, cheating, religion only as symbols and so on (Allport \& Ross, 1967). People make religion as a means to meet other needs outside of religion and have a great tendency to use their religiosity to achieve personal goals. Religion is not a guiding motive but religion is a means to an end to meet their needs and is only used as an instrument to achieve specific goals himself.

4.3.2.Hypothesis related to Job Satisfaction

First, organizational justice influences job satisfaction. The results of the research proved as previously thought that organizational justice influences job satisfaction. This finding is in line with research conducted by (Bingham, 1997; Tyler \& Lind, 1992). They stated that organizational justice results in individuals were being more satisfied, having a desire to accept resolution in procedures, and more likely to form a positive attitude towards the organization. The results of this research were also in line with the results of the reseaerch which examined organizational justice in building job satisfaction (Al-Zu'bi \& Box, 2010). There is a positive relationship between organizational justice and job satisfaction. Organizational justice describes individual perceptions about the fair treatment received from the organization and the behavioral reactions of employees to organizational justice. Likewise, a study Moorman (1991) examined the organizational justice model (distributive, procedural and interactional justice) found that all three dimensions of organizational justice affect job satisfaction. The findings of this study are also in line with the results of research on banking business in Iran that the three dimensions of organizational justice such as distributive, procedural and interactional are strong predictors of job satisfaction (Abasi et al., 2014). In the context of this research, fair behavior received by lecturers in terms of distributive justice (salary, reward, opportunities for self-development, promotion) significantly influenced lecturers' job satisfaction, as well as procedural justice, including transparency in work assessment and interactional justice including respect for superiors, good treatment, respecting the rights of lecturers significantly influences job satisfaction. Lecturers who get job satisfaction will be more committed to their campus. This finding was also in line with research that stated individuals who are treated fairly by the organization will develop and maintain a communal relationship with the organization (Kim et al., 2009). When individuals feel that they are treated fairly by their organization, they have more commitment, trust, satisfaction, and mutual control.

Second, religiosity does not affect job satisfaction. The findings of this research did not prove that religiosity affects job satisfaction. This finding was not in line with some of the results of previous studies that show that religiosity affects job satisfaction as research showed that there is acceptance of the expression of religiosity in the workplace and has a significant influence on job satisfaction on alumni of Christian Universities in America (King \& Williamson, 2005). Likewise, the research that examined employees in small and medium-sized embroidery business industries in Tasikmalaya, West Java, showed that the influence of Islamic religiosity on job satisfaction of employees (Amaliah, Aspiranti, \& Purnamasari, 2015). The research which examined BPKP auditors about the influence of religiosity and spirituality in preventing fraud, showed that religiosity affects individual behavior in the form of job satisfaction through attitude. Internalization of religiosity values affect ethical behavior and individual values, attitudes and job satisfaction. Thus attitude variables are intermediate variables that can encourage job satisfaction. The findings of these research were not in line with the results of this research. However, the findings of religiosity research on job satisfaction do not directly affect logical. Job satisfaction has nothing to do with one's belief in religion because the individual's inner nature is related to God whereas job satisfaction has more to do with humans in organizations (Purnamasari \& Amaliah, 2015). There was no basis that stated humans must gain satisfaction when working instead of human must try his best in working. 
Third, internal marketing has no effect on job satisfaction. This finding was not in line with some of the results of previous research which generally showed that internal marketing has an effect on job satisfaction as explained by Huang and Rundle-Thiele (2014). According to them, the context of organizations examining cultural congruence is the moderating variable between internal marketing and job satisfaction with tourism companies (tourism). In a research involving 458 tourism business employees in Australia, it empirically proved that the better internal marketing in organizations will increase job satisfaction, job satisfaction will ultimately improve organizational performance (Huang \& Rundle-Thiele, 2014). Likewise, study examined the effects of internal marketing programs on the perception of frontline employees in Bangladesh insurance companies. In this research, it was found that the internal marketing program was rated positively by frontline employees (FLE) resulting in employees who were satisfied with their work, job satisfaction results in better employee performance (Ferdous \& Polonsky, 2014). The research showed that organizational internal marketing can increase job satisfaction and organizational commitment (Rafiq \& Ahmed, 2000; Collins \& Payne, 1991; Tansuhaj et al., 1988). The results of this research were partially supported with research who examined the effects of internal marketing on job satisfaction. Using a sample of 401 frontline employees in various Saudi Arabian restaurant industries, it was found that internal marketing in the form of leadership commitment, internal communication and reward systems affected job satisfaction, while internal marketing in the form of training and development had no effect on frontline employee job satisfaction (Sohail, 2018). In line with Sohail's research, the results of this research did not prove that internal marketing has a direct effect on job satisfaction.

4.3.3. Hypothesis Related to Organizational Commitment

First, job satisfaction influences organizational commitment. This finding is in line with the results of research on satisfied teachers and principals that will influence student satisfaction and organizational commitment (Laschinger \& Finnegan, 2005: Testa, 2001; Fraser \& Brock, 2013). The research in Higher Education showed that lecturer satisfaction influences organizational commitment (Cohen et al., 2012). As one of the educational entities, Higher Education is unique in its social environment, work environment, quality of learning, managerial factors, academic atmosphere, relationships between lecturers, lecturers with employees, lecturers with students, structural relationships, satisfaction with these factors according to influences of organizational commitment.

Second, organizational justice does not directly influence organizational commitment. This finding was not in line with some of the results of previous studies which generally showed that organizational justice influenced organizational commitment (Dude, 2012). Job satisfaction and organizational justice affect organizational commitment (Hawkins \& Parks, 1998). The research showed that increased organizational justice would increase organizational commitment for BNI Margonda Bank employees, West Java (Nurmaladita \& Warsindah, 2015). Research on job satisfaction and organizational commitment showed that a fair income distribution affects job satisfaction, job satisfaction influences organizational commitment (Agho, Mueller, \& Price, 1993). The findings of this study are in line with the results in a study of 213 teachers in Canada, the results showed no relationship between organizational justice and organizational commitment, the findings in this research do not prove that organizational justice directly influences organizational commitment (Barling \& Phillips, 1993). Referring to the research that organizational justice cannot directly influence organizational commitment but through job satisfaction, job satisfaction is a predictor of organizational commitment (Bakhshi et al., 2009). Most of the literature supports procedural fairness in job satisfaction theory. In general, research showed that if organizational processes and procedures are considered fair, then individuals will be more satisfied, more willing to accept procedural resolutions and more likely to form positive attitudes about organizations (Bingham, 1997); (Tyler \& Lind, 1992).

Third, religiosity does not affect organizational commitment. This finding was not in line with some of the results of previous studies which generally showed that religiosity affects organizational commitment, study of 1220 samples of PT. Phapros Indonesia, BRI employees of the Central Java Regional Office, PLN employees in Central Java and employees of the Central Java Patra Hotel Services show that religiosity influences organizational commitment (Ghozali, 2002). Likewise, research showed that religiosity makes work more meaningful and influences organizational commitment (Gotsis \& Kortezi, 2008). The results of this research indicated that religiosity has no effect on organizational commitment. This result is in line with previous research showing that there is no relationship between religiosity with organizational commitment, especially on continuance commitment, continuous commitment is an assessment of the cost (sacrifice) felt by someone if there is no other alternative work (Farrukh, Ying, \& Ahmed, 2016). Research in Pakistani culture which is mostly Muslim, Islam teaches work is worship so it has nothing to do with organizational commitment (Farrukh et al., 2016).

Fourth, internal marketing has no effect on organizational commitment. This finding was not in line with some of the results of previous studies which generally showed that internal marketing influences organizational commitment (Barnes et al., 2004). This showed that internal marketing influences organizational commitment. Likewise, a research stated that internal marketing is the best approach to achieve organizational commitment. Internal marketing can increase job satisfaction and organizational commitment (Hogg, Carter, \& Dunne, 1998). The results of this research cannot prove that internal marketing has a direct effect on organizational 
commitment. This can be explained based on previous research of internal marketing that influences organizational justice (Aykan \& Sönmez, 2014). The results of this research indicated that internal marketing conducted by service companies on employees (Rafiq \& Ahmed, 2000) has an influence on organizational justice. Research found that organizational justice in the form of distributive, procedural and interactional justice significantly influences job satisfaction (Abasi et al., 2014) and job satisfaction of lecturers in research in Higher Education showed that lecturer satisfaction influences organizational commitment (Cohen et al., 2012). Based on these findings it is logical that internal marketing did not directly influence organizational commitment, but must go through organizational justice and job satisfaction.

4.3.4.The Effect of Religiosity on Job Satisfaction, Organizational Justice and Commitment

This research suspected that there was an influence of religiosity on job satisfaction, religiosity on organizational justice and religiosity on organizational commitment. However, the results of the research showed the opposite. There was no influence between religiosity on job satisfaction, organizational justice, and organizational commitment. The results of the research were logically not proven directly or indirectly because religiosity is examined for its effect on organizational life behavior while religiosity itself is one's belief in God that is internalized individually. From the perspective of religiosity, one's beliefs are seen from the normative side given. It means that the relationship between humans and God is good and it encourages to reach the highest level, but that is difficult to measure quantitatively. The degree of one's religiosity did not directly determine a person's behavior, whether if the religiosity is good then the behavior is also good or in other words the relationship with God can be very good but not necessarily the relationship with other human beings is also good. Based on these arguments, organizational commitment, organizational justice and job satisfaction as behavioral implementations were very likely not to have direct affect by religiosity. Understanding religiosity that did not affect organizational commitment, job satisfaction and organizational justice did not mean that no religion is okay. Religiosity is very important. It is just how to implement religiosity into daily life behavior including work. If it is related to the lecturers 'tasks, then how can the lecturers' religiosity be implemented in a better tridharma because in reality, there were lecturers who do not have organizational commitment even though they are religious.

In addition to the arguments above, the results of this research found a direct (indirect) and indirect (indirect) relationship between religiosity with organizational commitment and between internal marketing and organizational commitment mediated by organizational justice and job satisfaction. Furthermore, the relationship is explained as follows:

a. Relationship between Religiosity (X1) and Organizational Commitment (Y3).

Based on the research model, it can be analyzed that there was a direct or indirect relationship between religiosity (X1) and organizational commitment (Y3). The relationship between religiosity (X1) and organizational commitment (Y3) was directly based on the value of standardized direct effect that produced a coefficient of 0.035 , while the indirect relationship was the value of standardized indirect effect between religiosity (X1) and organizational commitment (Y3) through organizational justice (Y1) and job satisfaction (Y2) that produces a coefficient of 0.115 but not significant. It can be concluded that religiosity (X1) did not affect organizational commitment (Y3) either directly or indirectly through mediating variables of organizational justice (Y1) ) and job satisfaction (Y2).

b. The relationship between internal marketing (X2) and organizational commitment (Y3).

Based on the research model, it can be analyzed that there was a direct or indirect relationship between internal marketing (X2) and organizational commitment (Y3). The relationship between internal marketing (X2) and organizational commitment (Y3) was directly based on the value of standardized direct effect that produced a coefficient of 0.073 , while the indirect relationship was the value of standardized indirect effect between internal marketing (X2) and organizational commitment ( Y3) through organizational justice (Y1) and job satisfaction (Y2) of 0.085 and significant. Thus, it can be concluded that internal marketing (X1) and organizational commitment (Y3) were interconnected, both directly and indirectly through organizational justice (Y1) and job satisfaction (Y2). It can be said that internal marketing was the only exogenous construct that was capable of influencing organizational commitment. Why internal marketing does not directly affect organizational commitment but must go through organizational justice and job satisfaction first? This can be explained that internal marketing in principle was how to view employees as internal customers who need to be informed, trained, developed and motivated to be satisfied and can serve external customers effectively. Employees as individuals in the organization had needs and would consistently behave to maximize satisfaction, namely satisfaction at work. Satisfaction is a person's feelings of liking or disliking one's work. Therefore, satisfaction is related to one's feelings, likewise organizational justice is one's feeling whether he or she was treated fairly or not by the organization. Organizations that internal marketing practices well and behave fairly toward their employees will further increase employee satisfaction. This satisfaction will ultimately increase their commitment to the organization 


\section{Conclusion}

This research examined the internal marketing study of organizational commitment of lecturers of Private Universities in Indonesia. Conclusions was drawn from respondents' assessments of constructs which were tested well and very well. The results of the normality test showed that the research data was normally distributed as indicated by the criterion value of the critical ratio (cr) in the range of \pm 2.58 . The multicollinearity test results showed the determinant value of the covariance matrix was 0,000 . Even though the values close to zero were still acceptable, the number of samples were $>100$. It can be said that mutinolinierity did not occur. Measurement Model Test Results based on the results of the CFA (Confirmatory Factor Analysis) test can be shown that all indicators can confirm the latent variables studied with a significance value of 0.001 which was less than 0.05 . Besides this, the indicator can be declared valid as seen from the convergent validity or loading factor criteria of 0.50 . Based on the results of the standardized loading estimate, all indicators in the research had a loading factor $>$ 0.50 , which means a valid indicator measured the construct being tested.

The reliability test results can be shown from the construct reliability. There were four constructs that had a reliability value $\geq 0.70$. Only one construct had a reliability value of $0.644 \leq 0.70$. The value can still be said to be reliable because of its good validity. Thus, it can show construct validity to these five constructs which was reliable. Model Structural Test Results, Goodness of Fit assessment of the model, at an early stage can be shown that there were four criteria that were already fit and two criteria that were not fit yet. This was indicated by the value of Chi Square $(\chi 2)$ of 875,600 with a probability value of $0.000<0.005$. The probability value $<0.005$ of the model cannot be said to be good because it showed that the empirical data was not in accordance with the theory or the model and cannot be used to test the hypothesis.

Since based on the results of initial testing a good model had not been obtained, structural model modification tsting was done. Modification of the model was done by looking at the value of the modification indices on each relationship between variables. Modification index $\geq 3.84$ gave an idea of the decreasing value of Chi Square $(\chi 2)$. Based on the covariate relationship test, the value of modification indices was 3.84 and the decrease in chi square value became 292,205 with the probability of $0.104 \geq 0.05$. Goodness of Fit test resulted after modification of the model that showed all the criteria in this research were fit. According to Ghozali (2013), Goodness of Fit can be assessed based on five criteria and was not required to meet all criteria. The results of testing the research hypothesis could be concluded that four hypotheses were proven while the rest were not proven.

The most influential and significant variable on organizational commitment was job satisfaction with a coefficient value of 1,012. In other words, increasing job satisfaction will increase organizational commitment. Furthermore, organizational justice variables had positive and significant effect on job satisfaction with coefficient value of 0.867 . It can be said, increasing organizational justice will further increase job satisfaction. Likewise, internal marketing on organizational justice had positive and significant effect with coefficient value of 0.226 . It means that the higher the internal marketing, the higher the organizational justice.

\section{Research Contributions}

\subsection{Theoretical Contributions}

a. This research consisted of 5 constructs including 2 exogenous (independent) variables, namely religiosity and internal marketing and 3 endogenous (dependent) variables, namely organizational justice, job satisfaction and organizational commitment. After several stages of testing the model including modification, it showed that the research model had good goodness of fit. Therefore, this research model can be used for future research.

b. This research showed the following results: Religiosity does not affect organizational justice. The results of this research were in line with research who found that there was a controversial condition in a person that separated religious values with behavior including fair behavior in organizations. There people were very likely to be religious but not fair in behavior (Allport \& Ross, 1967). This finding strengthens the research conducted by Allport and Ross (1967).

c. Religiosity did not affect job satisfaction. The results of this research were in line with research that stated religiosity did not have direct influence on job satisfaction of BPKP auditor but through attitudes and behaviors (Purnamasari \& Amaliah, 2015). Therefore, attitude and behavior as mediating variables are needed.

d. Religiosity did not directly influence organizational commitment. The results of this research indicated that religiosity did not have significant and direct effect on organizational commitment. The findings of this research reinforced the research in Pakistani culture that was mostly Muslim. The values of religiosity are inherent in their work culture whereas work as religious obligation instead of work as organizational commitment (Farrukh et al., 2016).

e. Internal marketing influenced organizational justice. The results of this research indicated that in order to form organizational justice, Higher Education institutions need to practice good internal marketing (Aykan \& Sönmez, 2014). The findings of this research were in line with the findings practices of internal marketing conducted by service companies in Turkey shopping center. The results of his research showed that first, internal marketing conducted by service companies on employees had an influence on organizational 
justice. Second, internal marketing had significant effect on employee performance. The research recommended that businesses implement internal marketing practices that allow employees to feel the values of organizational justice in business. Thus, the findings of this research reinforced previous findings.

f. Internal marketing did not have direct effect on job satisfaction. The results of this research indicated that internal marketing did not have significant enough and direct influence on job satisfaction. These findings did not support the findings of previous studies which showed that internal marketing can increase job satisfaction (Collins \& Payne, 1991). The results of this research indicated that internal marketing did not have significant enough and direct influence on job satisfaction but required additional intermediate variables, namely organizational justice. These findings indicated that the practice of internal marketing would affect satisfaction after lecturers were treated fairly first.

g. Internal marketing did not have direct effect on organizational commitment. The results of this research indicated that internal marketing did not have significant and direct effect on organizational commitment. These findings did not support the findings of previous studies (Barnes et al., 2004; Hogg et al., 1998). However, when tested the relationship between internal marketing and organizational commitment through mediating variables, job satisfaction and organizational justice, the results of the study showed that job satisfaction and organizational justice were mediating variable between internal marketing and organizational commitment. This finding was in line with the research that stated internal marketing influences organizational commitment through job satisfaction (Rafiq \& Ahmed, 2000). The lecturers who got organizational justice would encourage the emergence of job satisfaction while job satisfaction encouraged organizational commitment. The lecturers perceived that internal marketing which was practiced by the institution really aimed to build organizational justice for distributive, procedural and interactional. The perceived justice of the lecturers influenced job satisfaction which ultimately influenced organizational commitment.

h. Organizational justice influenced job satisfaction. The results of this research indicated that lecturers' perceptions of fairness in organizations affected their job satisfaction in tertiary institutions. These findings were in line with the research that stated perceptions of fairness will affect job satisfaction (Al-Zu'bi, 2010). The findings of this research reinforced the previous findings (Moorman, 1991; Fernandes \& Awamleh, 2006).

i. Organizational justice did not have direct effect on organizational commitment. The results of this research indicated that organizational justice did not have significant enough and direct influence on organizational commitment but required additional mediating variables, namely job satisfaction. This finding reinforced previous findings (Barling \& Phillips, 1993).

j. Job satisfaction had positive effect on organizational commitment. The results of this research indicated that in order to build organizational commitment, lecturers needed to get job satisfaction first. This finding was in line with previous research in Higher Education which showeds job satisfaction influences organizational commitment (Cohen et al., 2012).

\subsection{Practical Contributions}

a. For organizational marketing practitioners, the findings in this research indicated that organizational commitment was influenced by various factors, namely organizational justice, religiosity, internal marketing practices and job satisfaction. This research also provided directions that supported marketing strategies in building organizational commitment. Thus, it can further satisfy external customers. It is important for organizational marketers to understand all aspects related to internal customer views of all constructs contained in this research model because the model built in this reseach was proven to have goodness of fit and can be replicated in a broader organizational context. Understanding the views of internal customers of the construct contained in the research model can increase organizational commitment. Therefore, it is expected to improve the performance of internal customers in this case Higher Education lecturers.

b. Based on the results of the research, it showed that in the field of services especially universities, internal marketing practices, organizational justice and job satisfaction were the main variables that drive the emergence of organizational commitment. The lecturers considered that internal marketing (training and development, internal communication, motivation) was a variable that needed to be considered in the management of Higher Education, because it directly affected the perception of organizational justice. Perception of justice had a direct effect on job satisfaction and job satisfaction had an effect on organizational commitment. Higher Education needed to design training programs and development that were clearly planned to improve the competence of lecturers. Internal communication was also needed to be built through various communication channels because internal communication was the main key to understanding members in the organization and fostering a sense of belonging. Likewise motivation, Higher Education must create an atmosphere and confidence in members that the college in which they work is the best Higher Education that can prosper the intrinsic and extrinsic needs of members of the organization.

c. The values of religiosity in this research did not directly affect job satisfaction, organizational justice and 
organizational commitment. This can be seen from several perspectives. The first perspective stated that a person had a controversial situation, one side is religious but religiosity did not affect the attitudes and behavior at work, for example practicing fair behavior at work as taught in religion, as well as related to commitment, religious people should have a good commitment as taught in religion, but the facts were often different, and so on (Allport \& Ross, 1967). The second perspective as found in the study was people work as ibadah (worship). The values of religiosity were inherent in working as part of worship. Thus, they did not care whether superiors will treat them fairly or not, satisfying or not is not an important issue (Farrukh et al., 2016). The third perspective for tertiary institutions in viewing this aspect of religiosity has practical implications for lecturers because work is part of religious practice. Thus, the consequences in working must be optimal in accordance with the tasks listed in the Tridharma of Higher Education. Likewise for the managers of tertiary institutions, the implementation of religious values needs to be realized in a more equitable, prosperous management in accordance with their duties and responsibilities.

\section{Limitations of Research and Future Research}

a. When hypothesis was tested on religiosity, the religiosity variable was proven not to to have direct or indirect effect on organizational commitment. This was because religiosity is one's belief which was hidden including the individual's relationship with his Lord. Was it relevant enough to use these hidden beliefs as variables in research when it is associated with quantitative research? It should be considered in subsequent religiosity studies to look at aspects that were more easily measured, for example religious knowledge, religious attitudes, religious behavior, and so on.

b. The religiosity variable in this research did not touch the aspects of behavior as a consequence of one's religiosity. For example, if someone was good in religiosity, behavior would also be good that reflected his religiosity. Future research can be developed by looking at good behavior as material for the research of one's religiosity.

c. This research did not use control variables, for example demographic variables of age, gender, income, and education. Research with undergraduate students of business majors in the United States showed the influence of control variables from gender. Women were more ethical than men. Religious respondents were more religious then those who were not (Albaum \& Peterson, 2006). A research was done on staff and manager where income in the organization was not the main source because this is a low commitment. Young managers were less committed than elder managers and female employees had higher commitments than male employees (Glisson \& Durick, 1988). According to the research on organizational behavioral, these demographic factors had influence on the assessment. Thus, the demographic bias in this research could not be prevented.

\section{References}

Abasi, E., Mohammadipour, R., \& Aidi, M. (2014). An Investigation of the Impact of Organizational Justice Dimensions on Job Satisfaction (Case Study: An Iranian Bank). Universal Journal of Management, 2(3), $132-137$.

Agho, A. O., Mueller, C. W., \& Price, J. L. (1993). An Investigation of the Impact of Organizational Justice Dimensions on Job Satisfaction. Human Relations, 46, 1007-1027.

Albaum, G., \& Peterson, R. A. (2006). Ethical Attitudes of Future Business Leaders: Do They Vary by Gender and Religiosity? Business \& Society, 45(3), 300-321. https://doi.org/10.1177/0007650306289388

Allen, N. J., \& Meyer, J. P. (1990). The measurement and antecedents of affective, continuance and normative commitment to the organization. Journal of Occupational Psychology, 63(1), 1-18. https://doi.org/10.1111/j.2044-8325.1990.tb00506.x

Allport, G. ., \& Ross, J. . (1967). Personal Religious Orientation and Prejudice. Journal of Personality and Social Psychology, 5(4), 432-443.

Alsalem, M., \& Alhaini, A. (2007). Relationship between Organizational Justice and Employees Performance. Aledari, 108, 97-110.

Al-Zu'bi, H. A. (2010). A Study of Relationship between Organizational Justice and Job Satisfaction. International Journal of Business and Management, 5(12), 102-109.

Amaliah, I., Aspiranti, T., \& Purnamasari, P. (2015). The Impact of the Values of Islamic Religiosity to Islamic Job Satisfaction in Tasikmalaya West Java, Indonesia, Industrial Centre. Procedia - Social and Behavioral Sciences, 211, 984-991. https://doi.org/10.1016/j.sbspro.2015.11.131

Ancok, D., \& Suroso, F. (1994). Psikologi Islam Solusi Islam atas Problem-Problem Psikologi. Yogyakarta: Pustaka Pelajar.

Aykan, E., \& Sönmez, E. (2014). Mediating Role of Perceived Organizational Justice between Internal Marketing Practices and Employee Task and Contextual Performance: A Shopping Center Implication. International Journal of Managerial Studies and Research, 2(7), 1-15.

Bakhshi, A., Kumar, K., \& Rani, E. (2009). Organizational justice perceptions as predictor of job satisfaction and 
organization commitment. International Journal of Business and Management, 4(9), 145-154. https://doi.org/10.5539/ijbm.v4n9p145

Bansal, H. S., Mendelson, M. B., \& Sharma, B. (2001). The impact of internal marketing activities on external marketing outcomes. Journal of Quality Management, 6(1), 61-76. https://doi.org/10.1016/S10848568(01)00029-3

Barling, J., \& Phillips, M. (1993). Interactional, Formal, and Distributive Justice in the Workplace: An Exploratory Study. The Journal of Psychology, 127(6), 649-656. https://doi.org/10.1080/00223980.1993.9914904

Barnes, B. R., Fox, M. T., \& Morris, D. S. (2004). Exploring the Linkage between Internal Marketing, Relationship Marketing and Service Quality: a Case Study of a Consulting Organization. Total Quality Management \& Business Excellence, 15(5-6), 593-601. https://doi.org/10.1080/14783360410001680080

Bell, E., \& Taylor, S. (2004). From Outward Bound to Inward Bound: The Prophetic Voices and Discursive Practices of Spiritual Management Development. Human Relations, 57(4), 439-466.

Berry, L. (1981). The Employee as Customer. Journal of Retailing Banking, 3, 25-28.

Berry, L., Hensel, J., \& Burke, M. (1976). Improving Retailer Capability for Effective Consumerism Response. Journal of Retailing, 52(3), 3-14.

Bies, R., \& Moag, J. (1986). Interactional Justice: Communication Criteria of Fairness. In: Lewicki, R.J., Sheppard, B.H. and Bazerman, M.H., Eds. Research on Negotiations in Organizations, 1, 43-55.

Bingham, L. B. (1997). Mediating Employment Disputes: Perceptions of Redress at the United States Postal Service. Review of Public Personnel Administration, 17(2), 20-30. https://doi.org/10.1177/0734371X9701700203

Brandt, E. (1996). Corporate Pioneers Explore Spirituality. Human Resource (HR) Magazine, 41(4), 82-87.

Brega, A., \& Coleman, L. (1999). Effects of Religiosity and Racial Socialization on Subjective Stigmatization of African-American Adolescents. Journal of Adolescence, 22, 233-242.

Brooks, G. (2002). Knowledge-based structures and organisational commitment. Management Decision, 40(6), 566-573. https://doi.org/10.1108/00251740210433954

Carrol, S. (2013). Addressing Religion and Spirituality in the Workplace. In K. I. Pargament (Ed.) (APA Handbook Of Psychology, Religion, And Spirituality:An Applied Psychology Of Religion And Spirituality) (Vol. 2). Washington, DC: American Psychological Association.

Caruana, A., \& Calleya, P. (1998). The effect of internal marketing on organisational commitment among retail bank managers. International Journal of Bank Marketing, 16(3), 108-116. https://doi.org/10.1108/02652329810213510

Chen, C., \& Yang, C. (2012). The Impact of Spiritual Leadership on Organizational Citizenship Behavior: A MultiSample Analysis. Journal of Business Ethics, 105, 107-114.

Chen, C., Yang, C., \& Li, C. (2012). Spiritual Leadership, Follower Mediators, and Organizational Outcomes: Evidence From Three Industries Across Two Major Chinese Societies. Journal of Applied Psychology, 42, 890-938.

Cohen, M. Z., Holley, L. M., Wengel, S. P., \& Katzman, R. M. (2012). A Platform for Nursing Research on Spirituality and Religiosity: Definitions and Measures. Western Journal of Nursing Research, 34(6), 798817.

Collins, B., \& Payne, A. (1991). Internal marketing: A new perspective for HRM. European Management Journal, 9(3), 261-270. https://doi.org/10.1016/0263-2373(91)90006-C

Colquitt, J. (2001). On the dimensionality of organizational justice: A construct validation of a measure. Journal of Applied Psychology, 86(3), 386-400.

Coomber, B., \& Louise Barriball, K. (2007). Impact of job satisfaction components on intent to leave and turnover for hospital-based nurses: A review of the research literature. International Journal of Nursing Studies, 44(2), 297-314. https://doi.org/10.1016/j.ijnurstu.2006.02.004

Dean, K., Forniciari, \& Safranski. (2008). The Ethics of Spiritual Inclusion. New York: Palgrave Macmillan.

Delener, N. (1994). Religious Contrasts in Consumer Decision Behaviour Patterns: Their Dimensions and Marketing Implications. European Journal of Marketing, 28(5), 36-53. https://doi.org/10.1108/03090569410062023

Dude, D. J. (2012). Organizational commitment of principals: The effects of job autonomy, empowerment, and distributive justice. Iowa Research Online, 1-136.

Farrukh, M., Wei Ying, C., \& Abdallah Ahmed, N. O. (2016). Organizational commitment: Does religiosity matter? Cogent Business \& Management, 3(1), 1-10. https://doi.org/10.1080/23311975.2016.1239300

Farwa, M., Moazzam, B., \& Nighat, A. (2015). Employee Religiosity: Impact on Job Stress and Job Satisfaction. Horizons, 9(2), 1-27.

Fatt, C., Khin, E., \& Heng, T. (2010). The Impact of Organizational Justice on Employee's Job Satisfaction: The Malaysian Companies Perspectives. American Journal of Economics and Business Administration, 2(1), 5663. https://doi.org/10.3844/ajebasp.2010.56.63 
Ferdinand, A. (2002). Structural equation modeling dalam penelitian manajemen. Semarang: Badan Penerbit Universitas Diponegoro.

Ferdous, A. S., \& Polonsky, M. (2014). The impact of frontline employees' perceptions of internal marketing on employee outcomes. Journal of Strategic Marketing, 22(4), 300-315. https://doi.org/10.1080/0965254X.2013.876077

Fernandes, C., \& Awamleh, R. (2006). Impact of organisational justice in an expatriate work environment. Management Research News, 29(11), 701-712. https://doi.org/10.1108/01409170610716016

Fraser, J., \& Brock, B. (2013). Catholic School Principal Job Satisfaction: Keys to Retention and Recruitment. Catholic Education. A Journal of Inquiry and Practice, 9, 424-440.

Fry, L. W., \& Slocum, J. W. (2008). Maximizing the Triple Bottom Line through Spiritual Leadership. Organizational Dynamics, 37(1), 86-96. https://doi.org/10.1016/j.orgdyn.2007.11.004

Fry, Louis, \& Kriger, M. (2009). Towards a theory of being-centered leadership: Multiple levels of being as context for effective leadership. Human Relations, 62(11), 1667-1696. https://doi.org/10.1177/0018726709346380

Fry, LW, \& Nisiewicz, M. (2013). Maximizing the Triple Bottom Line Through Spiritual Leadership. Stanford, California: Stanford University Press.

Ghozali, I. (2002). Pengaruh Religiositas Terhadap Komitmen Organisasi, Keterlibatan Kerja, Kepuasan Kerja dan Produktivitas. Jurnal Bisnis Strategi, 9, 1-13.

Ghozali, I. (2013). Model Persamaan Struktural Konsep \& Aplikasi dengan Program AMOS 21.0. Semarang: Badan Penerbit Universitas Diponegoro.

Glisson, C., \& Durick, M. (1988). Predictors of Job Satisfaction and Organizational Commitment in Human Service Organizations. Administrative Science Quarterly, 33(1), 61-81. https://doi.org/10.2307/2392855

Gotsis, G., \& Kortezi, Z. (2008). Philosophical Foundations of Workplace Spirituality: A Critical ApproachGotsis. Journal of Business Ethics, 78, 575-600. https://doi.org/DOI 10.1007/s10551-007-9369-5

Greenberg, J. (1987). A Taxonomy of Organizational Justice Theories. Academy of Management Review, 12(1), 9-22.

Gronroos, C. (1985). Internal Marketing-Theory and Pratice. American Association's Services Conference Proceeding.

Gruen, T. W., Summers, J. O., \& Acito, F. (2000). Relationship Marketing Activities, Commitment, and Membership Behaviors in Professional Associations. Journal of Marketing, 64(3), 34-49. https://doi.org/10.1509/jmkg.64.3.34.18030

Hackett, R. D., Bycio, P., \& Hausdorf, P. A. (1994). Further Assessments of Meyer and Allen's (1991) ThreeComponent Model of Organizational Commitment. Journal of Applied Psychology, 79(1), 15-23.

Hair, J. J. F., Black, W., Babin, B., Anderson, R., \& Tatham, R. (2006). Multivariate Data Analysis (6 ed.). New Jersey: Pearson Educational Inc.

Hartman, S., Yrle, A., \& Galle, W. (1999). Procedural and Distributive Justice: Examining Equity in a University Setting. Journal of Business Ethics, 337-351.

Haryono, S. (2016). Metode SEM untuk Penelitian Manajemen dengan AMOS LISREL PLS,. Bekasi: PT. Intermedia Personalia Utama.

Hawkins, W., \& Parks, D. (1998). PREDICTORS OF AFFECTIVE ORGANIZATIONAL COMMITMENT AMONG HIGH SCHOOL PRINCIPALS. 1-113.

Hicks, D. (2003). Religion and the Workplace: Pluralism, Spirituality, Leadership. Cambridge: Cambridge University Press.

Hogg, G., Carter, S., \& Dunne, A. (1998). Investing in People: Internal Marketing and Corporate Culture. Journal of Marketing Management, 14(8), 879-895. https://doi.org/10.1362/026725798784867563

Huang, Y.-T., \& Rundle-Thiele, S. (2014). The moderating effect of cultural congruence on the internal marketing practice and employee satisfaction relationship: An empirical examination of Australian and Taiwanese born tourism employees. Tourism Management, 42, 196-206. https://doi.org/10.1016/j.tourman.2013.12.005

Indriantoro, N., \& Supomo, B. (1999). Metodologi penelitian bisnis untuk akuntansi dan manajemen. Yogyakarta: BPFE.

Ketchand, A., \& Strawser, J. (1998). The Existence of Multiple Measures of Organizational Commitment and Experience-Related Differences in a Public Accounting Setting. 10, 109-137.

Kim, T. (Terry), Kim, W. G., \& Kim, H.-B. (2009). The effects of perceived justice on recovery satisfaction, trust, word-of-mouth, and revisit intention in upscale hotels. Tourism Management, 30(1), 51-62. https://doi.org/10.1016/j.tourman.2008.04.003

King, J. E., \& Williamson, I. O. (2005). Workplace Religious Expression, Religiosity and Job Satisfaction: Clarifying a Relationship. Journal of Management, Spirituality \& Religion, 2(2), 173-198. https://doi.org/10.1080/14766080509518579

Laschinger, H., \& Finnegan, J. (2005). Using Empowerment To Builts Trust And Respect In The Workplace: A Strategy For Addressing The Nursing Shortage. Nursing Economic, 23(1), 6-13. 
Leithwood, K., Seashore, K., Anderson, S., \& Wahlstrom, K. (2004). Review of Research: How Leadership Influences Student Learning. University of Minnesota, Center for Applied Research and Educational Improvement.

Locke, E. (1976). The Nature and Causes of Job Satisfaction Handbook of Industrial and Organizational Psychology. Rand Mc Nally College: Publishing Company.

Loi, R., Hang-Yue, N., \& Foley, S. (2006). Linking employees' justice perceptions to organizational commitment and intention to leave: The mediating role of perceived organizational support. Journal of Occupational and Organizational Psychology, 79(1), 101-120. https://doi.org/10.1348/096317905X39657

Luthans, F. (1992). Organizational Behavio. New York: Mc Graw Hill Company.

Masterson, S., Lewis, K., Goldman, B., \& Taylor, M. (2000). Integrating Justice and Social Exchange: The Differing Effects of Fair Procedures and Treatment on Work Relationship. Academy of Management Journal, 43(4), 736-748.

Meyer, J. P., \& Allen, N. J. (1991). A THREE-COMPONENT CONCEPTUALIZATION OF ORGANIZATIONAL COMMITMENT. Human Resource Management Review, 1(1), 61-89.

Meyer, J. P., Stanley, D. J., Herscovitch, L., \& Topolnytsky, L. (2002). Affective, Continuance, and Normative Commitment to the Organization: A Meta-analysis of Antecedents, Correlates, and Consequences. Journal of Vocational Behavior, 61(1), 20-52. https://doi.org/10.1006/jvbe.2001.1842

Mitroff, I., \& Denton, E. (1999). A Study of Spirituality in the Workplace. 40(4), 83-92.

Mokhlis, S. (2009). Relevancy and Measurement of Religiosity in Consumer Behavior Research. International Business Research, 2(3), 75-84. https://doi.org/10.5539/ibr.v2n3p75

Moorman, R. H. (1991). Relationship Between Organizational Justice and Organizational Citizenship Behaviors: Do Fairness Perceptions Influence Employee Citizenship? Journal of Applied Psychology, 76(6), 845-855.

Nabatchi, T., Blomgren Bingham, L., \& Good, D. H. (2007). Organizational justice and workplace mediation: a six-factor model. International Journal of Conflict Management, 18(2), $148-174$. https://doi.org/10.1108/10444060710759354

Nurmaladita, \& Warsindah, L. (2015). Pengaruh Keadilan Organisasi terhadap Komitmen Organisasi melalui Kepuasan Kerja pada Karyawan Bank BNI Kantor Cabang Utama Margonda, Depok, Jawa Barat. Seminar Nasional Cendekiawan, 746-754.

Pecchenino, R. A. (2009). Becoming: Identity and spirituality. The Journal of Socio-Economics, 38(1), 31-36. https://doi.org/10.1016/j.socec.2008.08.002

Peltier, J. W., Pointer, L., \& Schibrowsky, J. A. (2006). Internal Marketing and the Antecedents of Nurse Satisfaction and Loyalty. Health Marketing Quarterly, 23(4), 75-108. https://doi.org/10.1080/07359680802131582

Piercy, N., \& Morgan, N. (1991). Internal marketing-The missing half of the marketing programme. Long Range Planning, 24(2), 82-93. https://doi.org/10.1016/0024-6301(91)90083-Z

Purnamasari, P., \& Amaliah, I. (2015). Fraud prevention: relevance to religiosity and spirituality in the workplace. Procedia - Social and Behavioral Sciences, 211, 827-835.

Rafiq, M., \& Ahmed, P. K. (2000). Advances in the internal marketing concept: definition, synthesis and extension. Journal of Services Marketing, 14(6), 449-462. https://doi.org/10.1108/08876040010347589

Reder, M. (1982). Chicago Economics: Permanence and Change. Journal of Economic Literature, 20(1), 1-38.

Rozeboom, W. (1966). Scaling Theory and the Nature of Measurement. Synthese, 16(2), 170-233.

Sasser, W. E., \& Arbeit, S. P. (1976). Selling jobs in the service sector. Business Horizons, 19(3), 61-65. https://doi.org/10.1016/0007-6813(76)90053-7

Sekaran, U. (2003). Metode Penelitian Untuk Bisnis. Jakarta: Salemba Empat.

Sihombing, S. O., \& Gustam, M. (2007). The Effect of Internal Marketing on Job Satisfaction and Organizational Commitment: An Empirical Study in a University Setting. 1-14.

Siswato. (2007). Kesehatan Mental: Konsep, Cakupan dan Perkembangannya,. Yogyakarta: Andi.

Sohail, M. S. (2018). The impact of internal marketing on employee job satisfaction and customer satisfaction: empirical evidence from restaurant industry of Saudi Arabia. Middle East J. Management, 5(4), 321-339.

Stuckey, J. C. (2001). Blessed assurance The role of religion and spirituality in Alzheimer's disease caregiving and other significant life events. Journal of Aging Studies, 15, 65-94.

Tansuhaj, P., Randall, D., \& McCullough, J. (1988). A SERVICES MARKETING MANAGEMENT MODEL: INTEGRATING INTERNAL AND EXTERNAL MARKETING FUNCTIONS. Journal of Services Marketing, 2(1), 31-38. https://doi.org/10.1108/eb024714

Testa, M. R. (2001). Organizational Commitment, Job Satisfaction, and Effort in the Service Environment. The Journal of Psychology, 135(2), 226-236. https://doi.org/10.1080/00223980109603693

Tyler, T. R., \& Lind, E. A. (1992). A Relational Model of Authority in Groups. Dalam Advances in Experimental Social Psychology (Vol. 25, hlm. 115-191). https://doi.org/10.1016/S0065-2601(08)60283-X

Veličković, V. M., Višnjić, A., Jović, S., Radulović, O., Šargić, Č., Mihajlović, J., \& Mladenović, J. (2014). 
Organizational commitment and job satisfaction among nurses in Serbia: A factor analysis. Nursing Outlook, 62(6), 415-427. https://doi.org/10.1016/j.outlook.2014.05.003

Yiğitol, B., \& Balaban, O. (2018). Relationship between Organizational Justice and Employee Satisfaction: Evaluation of Human Resources Functions. EconWorld Lisbon Portugal, 1-9.

Yildiz, S. M., \& Kara, A. (2017). A unidimensional instrument for measuring internal marketing concept in the higher education sector: IM-11 scale. Quality Assurance in Education, 25(3), 343-361. https://doi.org/10.1108/QAE-02-2016-0009

Yousef, D. A. (2017). Organizational Commitment, Job Satisfaction and Attitudes toward Organizational Change: A Study in the Local Government. International Journal of Public Administration, 40(1), 77-88. https://doi.org/10.1080/01900692.2015.1072217 